\title{
Technology Integration in Schools Is We Overinvested and Underprepared?
}

\author{
S. Soujah
}

\begin{abstract}
The aim of this research is to examine the integration of technology and the barriers to its assimilation by students in the classroom. The work presented in this document was framed by a review of the academic literature, pedagogic experience as an educator and observations as a school administrator. The dual definition of technology as it relates to the user, digital native and digital immigrant, no longer holds value as the demographic saddled with the neophyte label has become fully assimilated into mainstream society and the digital natives have come of age. Despite the ubiquitous nature of technology, schools still struggle to make technology relevant and accessible to all students. Students living in poverty have less access and facility with technology than their more affluent peers. Teacher attitudes greatly affect the assimilation and use of technology by students. Their role in making technology accessible to underprivileged students is critical for success in adulthood. It is the opinion of this author that clarification of the purpose of technology is necessary to define the pedagogic approach of schools. Furthermore, teaching technology as an isolated subject is limiting and nearsighted. Efforts must be made to embed technology in all disciplines as a facilitator, not the end itself. A constructivist approach to education is advocated where technology becomes an invisible component of inquiry and learning.
\end{abstract}

Index Terms-Constructivist, schools, teacher attitudes, technology integration, underprivileged.

\section{INTRODUCTION}

The use of technology in Education is a controversial topic that often polarizes intellectuals and teachers. Educational thinkers like Andy Hargraves [1] Larry Cuban [2], [3], Wenglinsky [4] and many others have gone on record arguing the perils of overinvestment in Technology. Their contentions center on the delusion that technology is the panacea to cure all ills. They warn against the overreliance on technology and devotion to electronic tools. Just like a hammer is no more responsible for pounding a nail than a pen for writing a poem, technology is a sophisticated tool, rendered ineffective if improperly used.

Similarly, many authors have come in defence of technology. John Hattie, in his comprehensive book, Visible Learning [5] notes the benefits of integrating technology in education. However, his praise comes with many addendums that dilute his assertive statements about its value. Hattie warns that effectiveness is conditional upon the diversity of teaching strategies, training, and availability of multiple opportunities for learning, learning control, peer

Manuscript received October 16, 2013; revised December 18, 2013.

S. Soujah is the with Morden Collegiate Institute in Morden, Manitoba. $\mathrm{He}$ is also with the University of Nebraska and the Southern Region for the Manitoba Council of School Administrators, Lebanon (e-mail: ssoujah@westernsd.mb.ca). learning and optimization of feedback. Although the effectiveness of technology is buffered by circumstance and design, he nonetheless advocates for its implementation trusting in idealized scenarios of pedagogy and structure. Hattie is not alone in supporting technology integration. Cohen [6], Torgerson and Elbourne [7], Campagnone [8], and Wozney et al. [9] echo Hattie's findings.

The purpose of this document is to establish a framework for discussion integrating evidence from different sources to shed light on the purpose of technology in education and society at large. A distinction is made on the pedagogic use of technology and the instruction of hardware and software applications. Furthermore, observations and insights are provided to help guide future practice. The realm of Social Media and the use of networking platforms such as twitter and blogs are not reviewed as their treatment is far too complex and involved to be discussed under this particular heading and is deserving of its own treatise.

\section{Digital CitizenshiP}

The phrase digital native and digital immigrant, coined by Marc Prensky in Digital Natives, Digital Immigrants published in 2001 [10], and its subsequent treatment in education by Bennett, Maton and Kervin [11] and Bennet and Matton [12] is critical in establishing a framework of discussion for the relevance of technology in education today. The initial intent of the phrase was to distinguish between the demographic uses of technology. Young people were perceived to be more technologically astute given that they were immersed in the technology from an early age while older users were deemed to be less proficient and resistant to adapting the technology in their lives. However, this may no longer be the case as the generation that earned that label is fast becoming part of mainstream society [13] as time goes by, teachers trained surrounded by technology incorporate that presumed innate facility into their practice thus further negating Prensky's nomenclature

Research by Bennet and Maton [12] raises the likelihood that ease of use may be better defined by socio economic parameters than demographic differences. This possibility raises some interesting questions in regards to access and availability. It should be noted that the absolute number of computers in a classroom is not an accurate definition of access. Research suggests that although the presence of technology encourages its use, many factors affect its validity as a learning tool, none more important than the teacher itself. Nonetheless, it's been suggested by Mason and Dodds [14] that a digital divide exists between socioeconomic classes. Children raised in homes with available technologies have a learned predisposition to 
making use of technologies to problem solve, access information and communicate. The increased familiarity with computers, tablets and cell phones removes a cognitive barrier that often handicaps students less familiar with technologies. However, regardless of the lack of exposure, the learning curve for underprivileged students is steep and easily overcome, hence the need and value of technology in schools [15], [16]. This is evident in immigrant students who are exposed to technologies late in life and students from low socioeconomic background with little or no access to technology who invariably become native after a few years of use.

What does this mean for educators? If we accept the new socio economical definition of digital immigrants and digital natives, then an awareness of the technological literacy of students will help pedagogy and program design. Students are equally created but not equally raised and thus their background may greatly influence their learning, in particular, their ease with the use of technology.

\section{The Digital Divide}

Mason and Dodds [14] have written extensively about the consequences of the digital divide and the widening of the gap between "haves" and "have-nots". Underprivileged students are underexposed to technologies needed to develop $21^{\text {st }}$ century skills and hence unable to reach minimum standards. This vacuum of skills is all encompassing and far reaching beyond schooling, spilling into a myriad of societal ills: unemployment, poverty, and welfare.

How severe is the Digital Divide and what does it mean to schools today? Sun and Metros [17] and Mason and Dodds [14] have suggested that technological illiteracy gives rise to disadvantage futures. Lower socioeconomic demographics are at a disadvantage in the labor force and higher education as their skills or lack of pushes them behind their more affluent neighbors. It has been estimated that if this trend continues, "by 2015, African Americans and Latinos in the US would be underrepresented in managerial, technical, and educational jobs due to their lack of higher degrees. Therefore, it is important to ensure that students with low socio-economic status have equal access to technology in their early educational experiences" [17]. The long term effects are not restricted to employment intra-competition but also on a much larger global scale could spell disaster for the U.S. economic outlook. In his book, The World is Flat; Thomas Friedman [18] is clear and poignant in his doomsday predictions when" the playing field is leveled". The access to technology in third world countries will shift the locus of economic control. If the educational system in the U.S. cannot catch up its citizens to the digital divide quickly enough, those without will soon find them further alienated and disenfranchised, with few marketable skills and even fewer prospects for the future.

The democratization of schools ought to be a national priority free of economic constraints and budgetary ceilings. A re-evaluation of funding is imperative and a commitment to reduce the gap between well to do schools and those in impoverished neighborhoods is necessary to level the playing field in our own backyard. The irony of this dilemma is that in rich schools we are overinvested in technology while in poor districts there is a critical deficiency.

\section{The Purpose of TeChNOLOGY}

If Technology is narrowly assumed to be the application of scientific knowledge for practical purpose, then its teaching in school must be about problem solving and the implied means to accomplish it. Often schools, in their overzealous eagerness to be part of innovative practices, will jump on the bandwagon of whatever educational hool a hoop happens to be in vogue. Technology becomes the "event" instead of the pedagogic tool. Unfortunately, this is no different than the early demise of tracking, whole language, cultural literacy, didactic teaching, constructivism, or NCLB in terms of their value as authentic sustentative practices and ideologies [19].

The difficulty in defining the purpose of technology in pedagogy lies in its evolution from single use to its universal application. Technology is no longer the sole domain of the experts; it has become embedded in our social fabric. The use of technology from the mundane to the sophisticated has amplified its application to include every aspect of our condition as users.

What does this mean to educators? In essence, before we can agree on value, we need to evaluate technology in the context of instruction and learning. Teachers and students negotiate meaning with technology as dual entities, users and learners. Users have a far greater comprehension and intellectual ability in making that technology relevant to their needs. We must discern the effectiveness of technology in that context and reflect on its purpose for us and our students. In evaluating its effectiveness we must ask ourselves, are we effectively employing technology to the full extent of its capabilities? or is the hardware and software excessive to the needs of the user? Furthermore, are we using it to increase productivity, or is it a necessity given the nature of the task at hand? Lastly, is the technology used as a problem solving tool or a glorified school supply no different than a fancy pencil?

\section{Technology as a Pedagogic Tool}

Technology in its modern manifestation (the ball point pen was at one point considered revolutionary technology) has greatly enhanced the teaching profession. Technology is an effective pedagogic tool if properly administered. Teacher centered technologies like smart boards, software applications i.e. Power Point, and teaching aides associated with specific subject areas have widened the bag of tricks used by teachers to model and motivate learners, but have done very little to effectively teach the use of that particular technology to students. The aim is to shift the definition of technology from being a substitute for current practice to augmenting, modifying and eventually creating content, not just repackaging it.

For example, teachers who delude themselves into believing that the use of smart boards as a pedagogic tool teaches kids how to use technology do greater harm by mystifying technology than creating confidence of use. The 
mere presence of a smart board and its application in the delivery of a lesson without an opportunity for students to use that technology does little to engage the student as a user Student's external involvement as a passive audience is at odds with the educational philosophy that guides teachers' practice.

Nonetheless, the gains made in learning because of the inclusion of technology as a teaching tool are noteworthy and unprecedented. This is particularly true in constructivist teaching models that are student centered and share the responsibilities of learning with the classroom [20]. Interestingly, the presence of technology in a classroom also leads to a virtuous cycle in the use of that specific technology. Sahl and Windschitl [21] observed that teachers shifted their attitudes about constructivist teaching by their use of technology. Their belief of what constitutes "good teaching" defined their use of informational technology and their eventual amendment and integration into their teaching This is echoed by several educational academics who also suggest that the success of integrating technology into the classroom is largely dependent on teacher's attitudes and beliefs about technology. Ertmer [22] posited that "although the conditions for successful technology integration finally appear to be in place, including ready access to technology, increased training for teachers, and a favorable policy environment" sophisticated technology use is a rarity because of teacher pedagogical beliefs.

Curiously, the demographic shift in the profession itself as it relates to digital ethnicity, has given rise to new opportunities for students that merge relevance and interest in the classroom. For example, the inclusion of video games in teaching has been widely reviewed and scrutinized; and although the sophistication of the games does not permit content inclusion relevant to schooling yet, the development of parallel learning skills such as abstract thought, logic, memory, visualization and problem solving are valid elements worth encouraging through this media [23] Similarly," the affordances of Web 2.0 and social software" as exemplified by blogs, wikis, Facebook, etc... permit creative integration of information that gives rise to new and original thought unavailable prior to the development of these platforms [24].

What does this mean for educators? The context of education is such that often macro charismatic initiatives obscure the practical value of their application. The consensus from the research consulted suggests that first and foremost in determining effectiveness is the attitude and approach of the teacher. The success of implementation has less to do with expertise and more to do with willingness of integration and assimilation by the educator. Attitudes and beliefs are critical in facilitating acceptance and relevance of use in increasing learning in the classroom.

The competencies in technology necessary for successful assimilation into a digital world are numerous and often overwhelming. Word processing skills, familiarity with spreadsheets, email, web research, social media, and other similar functionalities have become necessities for success. The role of schools in facilitating the assimilation of these technologies is critical for the development of lifelong learners.

Productivity applications are not a novelty in schools. Their use has become ubiquitous across all disciplines. The challenge lies in the incorporation of the tool in everyday life as means of assisting in the learning process. The use of a power point (as an example) to give a presentation should not be treated as a novelty and ought to be part of the common lexicon in the classroom. Their adoption as a skill takes place early on in the education process and their continued practice reaches a level of acceptable proficiency by graduation. The rapid pace of change in technology makes it difficult to keep up financially and train teachers to demonstrate the skills. This necessitates a triage of essential skills to help adapt new technologies as they emerge. Similarly, it requires a steering committee to define what these skills are and what software applications ought to be taught to assist in productivity and future learning.

\section{CONCLUSION}

It is paradoxical that in an age where although the currency of choice is information, conversations about teacher attitudes towards ITC in the classroom still loom in the horizon and dictate the agenda of integration. Notwithstanding the pitfalls of the transition into a digital world, technology education is as ubiquitous as reading, writing and arithmetic. Its synergization with pedagogic practice ought to be seamless.

Although most teacher education programs pay particular attention to technology integration into their instruction of new teachers, the emphasis seems to be on hardware and software competencies not paradigms or attitude changes. This gives rise to egocentric application of knowledge in their eventual classrooms. Technology becomes a teacher privilege that does not translate well into student learning. On the surface, the availability of technology leads one into misunderstanding its scope within the classroom. True integration means active student participation first at a rudimentary level(involving limited application and practice learning of specific software programs) and then creative and critical use of technologies to produce new and original work.

The teacher's role in a constructivist classroom is to scaffold their learning by introducing the elements of inquiry with technology as a facilitator, not the purpose itself. As indicated earlier, the aim is to shift the use of technology from augmenting and modifying to eventually creating original content.

\section{REFERENCES}

[1] A. Hargraves, Personal Communication at Leading and Learning COSL Conference held in Winnipeg, Manitoba, February 16-17, 2012.

[2] L. Cuban, Teachers and machines: The classroom use of technology since 1920, New York: Teachers College Press, 1986, ch. 4.

[3] L. Cuban, H. Kirckpatrick, and C. Peck, "High Access and Low Use of Technologies in High School Classrooms: Explaining an Apparent Paradox," American Educational Research Journal, vol. 38, no. 4, pp. 813-834, Spring 2001

[4] H. Wenglinsky, "Technology and Achievement: The Bottom Line," Educational Leadership, vol. 63, no. 4, pp. 29-33, 2005

[5] J. Hattie, Visible Learning: A Synthesis of Over 800 Meta-Analyses Relating to Achievement, $1^{\text {st }}$ ed., Routledge Publishers, 2009, ch. 4-8.

[6] V. Cohen, "Learning Styles and Technology in a Ninth-Grade High School Population," Journal of Research on Technology in Education, vol. 33, no. 4, pp. 355-366, Summer 2001.

[7] C. J. Torgerson and D. Elbourne, "A systematic review and metaanalysis of the effectiveness of information and communication 
technology (ICT) on the teaching of spelling," Journal of Research in Reading, vol. 25, issue 2, pp. 129-143, 2002.

[8] S. Campagnone. (2005). The Effects of Graphing Calculators on Student Performance. [Online]. Available: http://hdl.handle.net/10428/327

[9] L. Wozney, V. Venkatesh, and P. Abrami, "Implementing Computer Technologies: Teachers' Perceptions and Practices," Journal of Technology and Teacher Education, vol. 14, no. 1, pp. 173-207, 2006.

[10] M. Prensky, "Digital Natives, Digital Immigrants," On the Horizon, vol. 9 no. 5, pp. 1-6, October 2001.

[11] S. Bennet, K. Maton, and L. Kervin, "The 'digital natives' debate: A critical review of the evidence," British Journal of Educational Technology, vol. 39, issue 5, pp. 775-786, September 2008.

[12] S. Bennet and K. Maton, "Beyond the 'digital natives' debate: Towards a more nuanced understanding of students' technology experiences," Journal of Computer Assisted Learning, vol. 26, issue 5 , pp. 321-331, October 2010.

[13] B. Kennedy, S. Bennett, T. Judd, K. Gray, and R. Chang, "Immigrants and natives: Investigating differences between staff and students' use of technology," presented at the Ascilite Conference, Melbourne, Australia, 2008.

[14] C. Mason and R. Dodds, "Bridging the Digital Divide," NAESP: Principal-Closing the Gaps, vol. 84 no. 4, pp. 24-30, March/April, 2005.

[15] S. Dika and K. Singh, "Applications of Social Capital in Educational Literature: A Critical Synthesis," Review of Educational Research, vol. 72, no. 1, pp. 31-60, Spring 2002.

[16] H. Blossfeld and Y. Shavit, Persistent Inequality: Changing Educational Attainment in Thirteen Countries, Social Inequality Series, Boulder, CO: Westview Press, ch. 2.

[17] J. Sun and S. Metros, "The Digital Divide and Its Impact on Academic Performance," US-China Education Review A 2, pp. 153$161,2011$.

[18] T. Friedman, "The World Is Flat," A BriefHistory of the Twenty-first Century, $1^{\text {st }}$ ed., Farrar, Straus and Giroux, 2005, ch. 6.

[19] Report by the Foundation for Critical Thinking. (2012). [Online]. Available: http://www.criticalthinking.org/
[20] H. Becker and J. Ravitz, "The influence of computer and Internet use on teachers' pedagogical practices," Journal of Research on Computing in Education, vol. 31, issue 4, pp. 356, Summer 1999.

[21] K. Sahl and M. Windschitl, "Tracing Teachers' Use of Technology in a Laptop Computer School: The Interplay of Teacher Beliefs, Social Dynamics, and Institutional Culture," Am Educ Res J, vol. 39, no. 1, pp. 165-205, March 2002.

[22] P. Ertmer. (2005). Teacher Pedagogical Beliefs: The Final Frontier in Our Quest for Technology Integration? Association for Educational Communications and Technology. [Online]. Available: http://www.aect.org/intranet/publications/index.asp

[23] A. Amory, K. Naicker, J. Vincent, and C. Adams, "The use of computer games as an educational tool: identification of appropriate game types and game elements," British Journal of Educational Technology, vol. 30, issue 4, pp. 311-321, October 1999.

[24] C. McLoughlin and M. Lee, "Social software and participatory learning: Pedagogical choices with technology affordances in the Web2.0 era," presented at the Ascilite Conference, Nanyang Technical University, Singapore 2007.

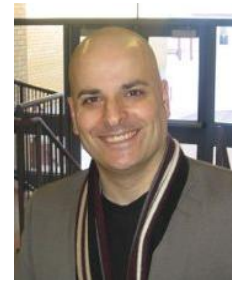

R. Soujah was born in Beirut, Lebanon. He is a doctorate student at the University of Nebraska, Lincoln, focusing on Administrative Leadership. He also holds undergraduate degrees in Environmental Science (University of Toronto 1990), Secondary Education (University of Regina 1994) and a Masters of Education on Technology (University of Southern Queensland 2003).

He is currently the Principal at Morden Collegiate Institute in Morden, Manitoba. He has been an administrator for nine year following a teaching career spanning over ten years. His academic work includes articles and presentations on media studies (The Impact of Cinema in the Classroom) cyberbullying (Cyber Bullying: the Role of Schools and Community in Preventing Online Harassment), and achievement (Mind The Gap: Gender Differences In Achievement In BC.)

Mr. Souhail Soujah is a Regional director for the Council of School Leaders in Manitoba and a member of various provincial educational organizations. 